\title{
Rooftop solar energy as an alternative source of energy for daily use by local communities from Kamdini sub-County, Oyam district, Uganda.
}

\author{
Daniel Ameny ${ }^{1}$ and Alex Barakagira ${ }^{1,2 *}$ \\ ${ }^{1}$ School of Sciences, Nkumba University, P.O. Box 237, Entebbe, Uganda. \\ ${ }^{2}$ Faculty of Science, Kyambogo University, P.O. Box 1, Kyambogo, Kampala, Uganda. \\ *Corresponding author: abarakagira@kyu.ac.ug
}

ORCID iD: https://orcid.org/0000-0002-0305-9193

\begin{abstract}
In Uganda, most parts of the country are not connected to the national grid that supplies hydroelectricity and those that are connected, occasionally face intermittent power supplies that stagnate smooth running of daily household activities and some microbusinesses. This prompted some members of the local community to start utilizing rooftop solar energy as an alternative source of energy for their household use. A total of 63 households and 67 microbusinesses were randomly and systematically selected respectively, to determine the distribution and reasons for the use of rooftop solar energy; the reliability of roof top solar energy to meet the people's energy demands; and to explore the cost implications members of the local community incur while utilizing rooftop solar energy. It was revealed that rooftop solar energy is utilized by most (95\%) of the respondents for lighting, charging mobile phones, air conditioning among others, because it is reported to be reliable. A fairly positive
\end{abstract}


relationship $(\gamma=0.492 ; \mathrm{P}<0.05)$ between previous and present use of rooftop solar energy by members of the local community implies the continuous use of rooftop solar energy in the study area. The respondents incurred expenses for acquisition of solar panels, inverters, stabilizers and other solar accessories. The study revealed a relationship between the individual's income and acquisition of roof top solar energy accessories $(\gamma=0.057 ; \mathrm{P}=0.560)$. This implies that the more the income of the respondents, the higher the purchasing power of the solar power accessories. There was no association between the level of education of the respondents and use of rooftop solar energy $\left(\chi^{2}=37.38 ; \mathrm{df}=1 ; \mathrm{P}=0.05\right)$ in the study area. In addition, household size of the respondents was not associated with the use of rooftop solar energy $\left(\chi^{2}=71.48 ; \mathrm{df}=1 ; \mathrm{P}=0.05\right)$. In a long run, rooftop solar energy once installed is more reliable, less costly and it is more preferred to be used compared to other energy sources.

Keywords: Alternative Energy Demands; Energy Costs; Power Reliability; National Power Supplies; Uganda.

\section{Introduction}

The PhotoVoltaic (PV) effect was discovered by Becquerel in 1839 while studying the effect of light on electrolytic cells and owing to the space programmes and use of satellites, further stimulated the development of crystalline Si (c-Si) solar cells with efficiency of $6-10 \%$ [1]. The c-Si cells were later replaced with polycrystalline Si cells (pc-Si) which are solar cells based on compound semiconductors (III-V and II-VI) in 1960s and they provided high production capacity at reduced material consumption and energy input in the fabrication process as reported by International Renewable Energy Association (IRENA) and the International Energy Agency's (IEA) Energy Technology System Analysis Programme (EISAP) [2]. Also, it was reported [2] that solar PV cells convert sunlight directly into electricity and currently, c-Si and thin-film (TF) technologies dominate the global PV market. In Uganda, most parts of the country are not connected to the national grid that supplies hydroelectricity [3]. Even then, those areas that are connected to the national grid are facing poor electricity services punctuated with intermittent power supplies, locally known as load shedding; which are known to have stagnated the smooth running of daily household cottage activities and other micro-businesses [4]. This prompted some members of the local community to start utilizing rooftop solar energy as the main alternative source of energy for 
household use. Some other energy sources as reported by MOEMD [5], include the use of kerosene, thermal, petrol generators, and biomass (wood fuel). Some other parts of Uganda including Kalangala district (Islands in Lake Victoria), embarked on the use of solar energy under the auspices of the Kalangala Infrastructure Services (KIS) project that serves the Island residents with renewable electricity amounting to $0.6 \mathrm{MW}$ of power, which is a low power supply compared to the energy demands of the residents [3]. It was further reported that because of the little wattage provided by solar energy in the Kalangala, a 1MW thermal power plant was installed in order to provide a 24-hour electricity to about 2000 households which was expected to spur investment in the hospitality industry, whose operators had long complained about the lack of reliable power supplies [3].

Globally in some other countries like California, because of a decline in solar power installation costs, $25 \%$ of the Country's electricity came from renewable resources in 2016 and was expected to reach $33 \%$ by the year 2020 [6]. Sherwood [7] reported that $490 \mathrm{MW}$ of photovoltaic capacity was being obtained from solar power, supplying to about 230,000 households [8] as a result of million solar roof initiative.

In Africa, after realizing that most of the members of the local community did not have access to the national grid, an initiative under the Akon lighting Africa was conceived to try and avail solar power electricity to at least 600 million Africans which culminated into launching an academy aimed at teaching people how to install and maintain solar-powered electricity systems [9].

In Uganda, after realizing that there was an acute power supply of between $90-210 \mathrm{MW}$ that affected most sectors of the economy, which accounted for the decline of the Country's economic growth rate at $4.5 \%$, instead of the projected $6.5 \%$ in 2006 [3], rooftop solar energy was then recommended to augment other sources of energy for a smooth running of the industrial and other activities including those undertaken in Oyam district. This was reportedly aimed at lowering the degree at which members of the local community relied on wood fuel (biomass energy) for energy sources that contributed energy equivalent to $241 \mathrm{PJ}$ used by different households in the year 2002 [5]. It was observed that firewood consumption in Uganda exceeds production [5] and that it had resulted in pressure on the natural vegetation, culminating in soil erosion and silting of water bodies $[10,11,12]$. The use of wood fuel also contributes to degradation of vegetation and jeopardizes availability of fodder since substantial amounts of wood are needed to generate huge amounts of fuel for community use $[10,13]$. In addition to loss of flora, deforestation as a result of over consumption of firewood leads to loss of fauna [11], and also leads to desertification 
especially in arid and semi-arid areas $[13,14,15]$. The use of huge amounts of wood fuel to generate energy has also been attributed to its lower calorific value as compared to other fuels like gasoline and Kerosine that produces $44 \mathrm{MJ} / \mathrm{kg}$ and $13 \mathrm{MJ} / \mathrm{kg}$ respectively [10]. Adanu and others [16] reported that, utilization of wood fuel is mainly considered as a cheap energy source which in most cases does not require any efficiency during its use. The authors pointed out that since women and children are the ones involved in fetching the wood, the labour used is free and also that, the wood in most cases is not bought, the situation that accelerates deforestation. In addition to industrial and service sectors, wood fuel is used for baking, brewing, brick making, warmth and to some extent light [10-12, 15]. The host of uses provided by wood fuel mainly in developing countries, encourages its indiscriminate and unsustainable harvesting, leaving the ground with little or no vegetation, that promotes evapotranspiration and leads to a reduction in soil fertility [12, 15, 17]. Mercer and Soussan [13] assert that, environmental collapse associated with droughts, floods and extreme climatic events are as a result of unsustainable wood fuel harvests. Some other scholars $[15,18]$ reported that loss of trees for wood fuel and charcoal production in arid regions breaks the chain of essential nutrient cycles which eventually leads to desertification.

Therefore, alternative sources of energy must be sought in order to halt or decrease the rate at which trees are cut that may culminate into further degradation of the environment, which may contribute to serious effects like global warming. A study was therefore initiated to assess whether rooftop solar energy may be used as an alternative source of energy to meet the daily energy uses by members of the local community in Kamdini sub-Country, Oyam district. The objectives of this study were three-fold, namely:

i. To determine the distribution and reasons for the use of rooftop solar energy among the households in Kamdini sub-County;

ii. To assess the reliability of rooftop solar energy towards meeting energy demands to members of the local community in Kamdini sub-County; and

iii. To explore the cost implications brought about by the use of rooftop solar energy to members of the local community in Kamdini sub-County.

\section{Study Area and Study Population}

The study was carried out in Kamdini sub-County, Oyam district found in northern Uganda (Fig. 1). The main reason for choosing Kamdini sub-County was that its population had 
previously been using solar energy alongside other sources of energy like the use of biomass, kerosene, petrol in generators and to some extent hydroelectricity [19].

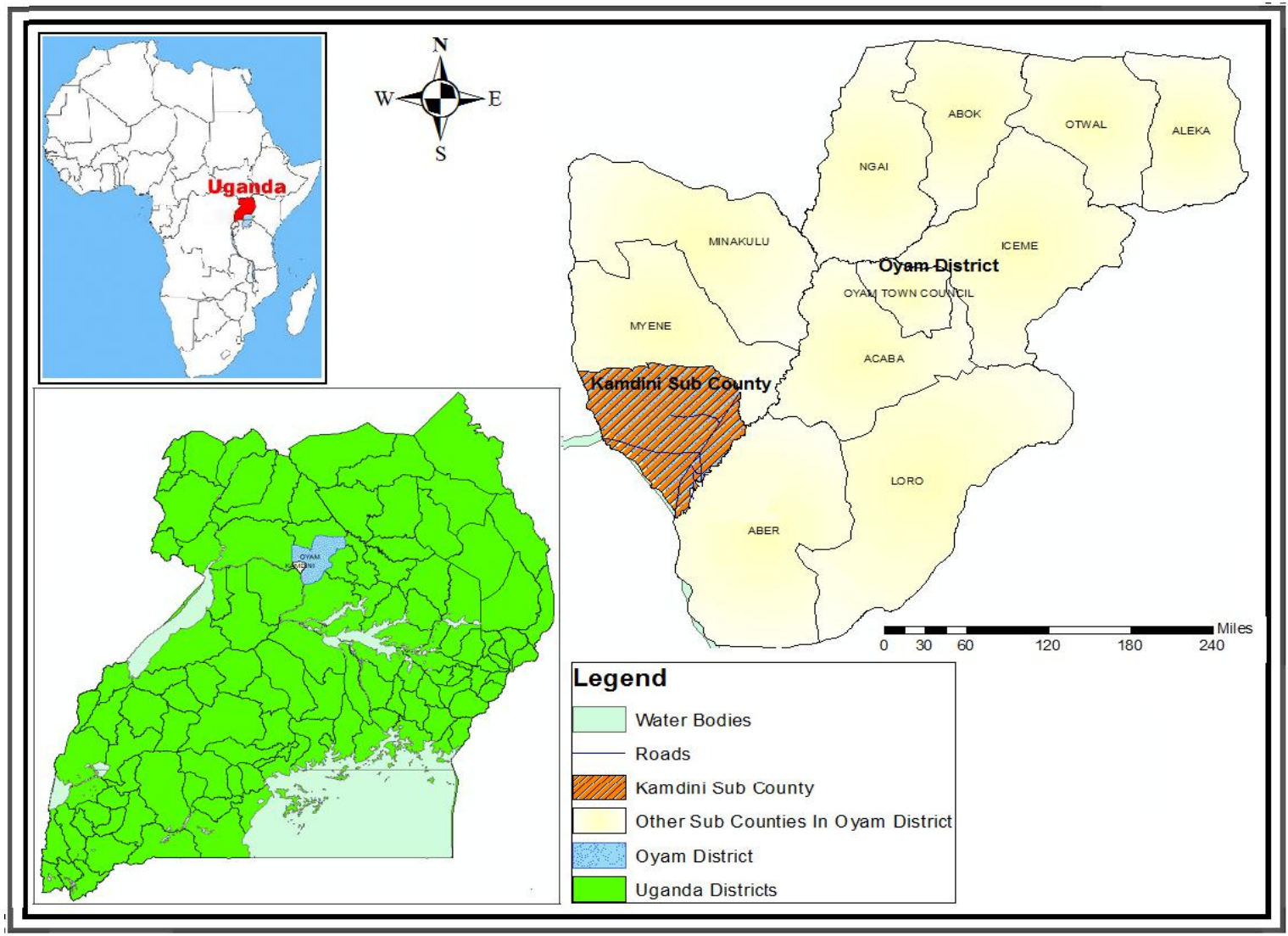

Fig.1 Map showing location of Kamdini sub-County found in Oyam district

The study targeted about 100 households located around some trading centres within Kamdini sub-County. In addition, 140 micro-businesses which are located within the trading centres found in Kamdini sub-County were also targeted to be included in the study. It was assumed that the residents of these areas either use solar energy, or have some requisite information about the use of solar energy. From the target population, the sample size was then determined using Yamane's formula [20]; $\mathrm{n}=\mathrm{N} / 1+\mathrm{N}(\mathrm{e})^{2}$; where $\mathrm{n}$ is the sample size to be included in the study; $\mathrm{N}$ is the target population (240); and e is the level of confidence (0.05). Hence, total sample size was calculated as: $n=240 / 1+240(0.05)^{2} ; n=150$. Hence, total sample size from the two categories of respondents was 150 .

\section{Materials and Methods}

The research project was centred on determining the number of households utilizing rooftop solar energy and reasons for its preference in Kamdini sub-County,and; assessing the reliance and adequacy of rooftop solar energy towards meeting energy demands to members of the 
local community in Kamdini sub-County; and to explore the cost implications brought about by the use of rooftop solar energy to members of the local community in Kamdini subCounty, Oyam district, Uganda.

This study adopted a descriptive cross-sectional survey with both qualitative and quantitative data structures used to obtain information about the use of rooftop solar energy as an alternative source of energy to meet the local people's daily energy uses. Qualitative data is used to verify and enrich the quantitative data which is obtained from the study [21, 22]. A series of complementary methods were used to collect a vast amount of data with the advantage that the methods enhanced the capacity for interpreting the data captured [23]. Questionnaires were used to collect primary data from the respondents who resided around the trading centres in the study area, and also from those individuals who owned some microbusinesses in Kamdini sub-County.

The questionnaire used was pre-tested in one sub-County in Oyam district that was not part of the selected sample. Pre-testing allowed the interviewers to gain familiarity with the questionnaire and provided an opportunity to apply and review the method. The focus was on assessing how respondents understood the questions and to identify any problems encountered in providing answers. Changes were proposed, reviewed and incorporated into the final questionnaire. The questionnaire focused on the respondents' understanding of the reliability and adequacy of rooftop solar energy towards meeting energy demands to members of the local community; and also, about the cost implications of using rooftop solar energy to members of the local community.

A questionnaire survey was conducted among sixty-three (63) households found in areas around the trading centres and sixty-seven (67) micro-businesses located along KampalaGulu highway in Kamdini sub-County. These were the aggregate sample sizes determined from the total target population of 240. Using Sarndal's formula [24]; $n_{i}=N_{i} / N$ X n; where $n_{i}$ is aggregate sample size; $\mathrm{N}_{\mathrm{i}}$ is target population; $\mathrm{N}$ is total target population; $\mathrm{n}$ is the total sample size; the aggregate samples were calculated as:

The number of the households that were included in the study; $\mathrm{n}_{1}=100 / 240 \times 150=63$ households. In addition, the number of the microbusinesses that were included in the study; $\mathrm{n}_{2}=140 / 240 \times 150=87$ microbusinesses. During the survey, there was $100 \%$ response rate from the households while a total of 67 respondents out of 87 representing the response rate of $77 \%$, from the individuals who owned the micro-business participated in the study. The 
sixty-three households were randomly selected, while the sixty-seven microbusinesses found along Kampala-Gulu highway were selected by systematic random sampling technique, where the first micro-business was randomly selected and the successive microbusinesses were selected after every second microbusiness. In each case, one adult person (18 years and above) from each household and microbusiness was selected, approached, briefed and informed that the purpose of the research was purely academic and had no legal implications whatsoever and that the respondents were also assured of confidentiality and anonymity. The questionnaire was then administered to the respondents to collect the required information concerning the use of rooftop solar energy as an alternative source of energy to meet the local peoples' daily energy uses.

Questionnaire responses were edited, coded and analyzed using SPSS version (IBM-SPSSversion 20.0) for windows. This informed descriptive and inferential statistics concerning rooftop solar energy as an alternative source of energy to meet the local people's daily energy uses. The analyzed data was then accompanied with notes to direct the readers' attention to important values for comparison. Percentage values, cross-tabulation values between the dependent and independent variables were used to relate what is in the tables together with the likely cause of the outcome. Generalizations of the data was made while reporting on the data based on the percentages and cross-tabulation values for particular items in the study. Generalizations ensures extrapolation of the research findings beyond the boundaries of the research sample to the whole population [21].

Qualitative data collected during key informant interviews were sorted and categorized into themes according to particular items of interest [21]. In some cases, the Pearson productmoment correlation coefficient was used to reflect the extent of a linear relationship between the dependent and independent variables in the study. Also, the Chi-square was used to test the extent of association that exist between different attributes of the respondents.

\section{Results}

\subsection{Household Characteristics}

The majority (92\%) of the respondents were males and $39 \%$ of the respondents were of average age of twenty-six years. Most respondents (64\%) studied beyond the primary seven levels of Education (elementary level). The study revealed that there was no association between the level of education of the respondents and the use of rooftop solar energy 
$\left(\chi^{2}=37.38 ; \mathrm{df}=1 ; \mathrm{P}=0.05\right)$. This implies that whether educated or not, members of the community opted to use rooftop solar energy probably because of immense uses it offered (Table 2). The main occupation of the respondents was farming. Their other source of income included petty trade in household items, bar owners and a few operating small health centres. Other respondents (5\%) were civil servants. About $47 \%$ of the respondents had an average household size of thirteen family members of whom, about $88 \%$ of respondents had some knowledge concerning solar energy as a source of energy (Table 1). Household size of the respondents was not associated with the use of rooftop solar energy $(\chi 2=71.48 ; \mathrm{df}=1 ; \mathrm{P}=0.05)$. This implies that irrespective the size of the household of the respondents, they still opted to use rooftop solar energy probably because it could be used for various functions and also, it was reliable.

Table 1. Household characteristics of respondents (Source: Researcher's Questionnaire Survey, 2017)

\begin{tabular}{|c|c|c|}
\hline Characteristic & Frequency & Percent \\
\hline \multicolumn{3}{|l|}{ Gender } \\
\hline Male & 119 & 91.5 \\
\hline Female & 11 & 8.5 \\
\hline \multicolumn{3}{|l|}{ Age } \\
\hline $11-20$ & 11 & 8.5 \\
\hline $21-30$ & 50 & 38.5 \\
\hline $31-40$ & 35 & 26.9 \\
\hline $41-50$ & 28 & 21.5 \\
\hline $50+$ & 6 & 4.6 \\
\hline \multicolumn{3}{|l|}{ Level of Education } \\
\hline No Education & 3 & 2.3 \\
\hline Primary (Elementary) & 44 & 33.8 \\
\hline Secondary & 65 & 50.0 \\
\hline Tertiary & 18 & 13.8 \\
\hline \multicolumn{3}{|l|}{ Occupation } \\
\hline Peasant & 51 & 39.2 \\
\hline Businessperson & 51 & 39.2 \\
\hline Civil servant & 18 & 13.9 \\
\hline Fishermen & 3 & 2.3 \\
\hline
\end{tabular}




\begin{tabular}{|c|c|c|}
\hline Other, like operating clinic & 7 & 5.4 \\
\hline Household size & & 53.1 \\
\hline $1-5$ & 69 & 29.2 \\
\hline $6-10$ & 38 & 16.1 \\
\hline $11-15$ & 21 & 0.8 \\
\hline $16-20$ & 1 & 0.8 \\
\hline
\end{tabular}

\subsection{Distribution and reason for the use of rooftop solar energy among the}

\section{households in Kamdini sub-County}

The majority of the respondents (95\%) reported that they utilize solar energy for various activities, where some members of the local community (39\%) as compared to $43 \%$ of the respondents who own some microbusinesses stated that that they utilize solar energy to answer some needs that require the use of energy. Some other members of the local community $(6 \%)$ compared to $8 \%$ of the respondents who own some microbusinesses reported that they utilize solar energy to answer all the needs that require the use of energy. The solar energy is used for various purposes by members of the local community, which include lighting (96\%) and charging of mobile phones (86\%), followed with air conditioning $(21 \%)$ and then ironing clothes (18\%), followed by the cooking of food (17\%). Other sources of energy utilized by the respondents include hydroelectricity $(22 \%)$, Kerosene used in lamps (17\%), fuel in a generator (16\%) and biomass (wood) energy (8\%) as observed in Table 2.

Table 2. Solar energy uses by the respondents (Source: Researcher's Questionnaire Survey, 2017)

\begin{tabular}{|c|c|c|}
\hline Solar energy use & Number & Percentage* \\
\hline Lighting & 125 & 86.2 \\
\hline Charging mobile phones & 112 & 20.8 \\
\hline Air conditioning & 27 & 17.6 \\
\hline Ironing clothes & 23 & 16.9 \\
\hline Cooking of food & 22 & 6.9 \\
\hline
\end{tabular}

*Total percentage of cases is more than $100 \%$ because of multiple responses. 


\subsection{Reliability of rooftop solar energy towards meeting energy demands to members of the local community}

As reported above (section 4.2), a host of uses is obtained from the solar energy by members of the local community from Kamdini sub-County. These include among others, lighting (96\%), charging of mobile phones (86\%), and air conditioning (21\%) which the respondents reported that the services do not attract monthly bills. The respondents further reported that there is no load shedding when rooftop solar energy is used as compared to the load shedding experienced by some households and microbusiness owners who depend on the national grid for hydroelectricity. They stated that the hydroelectricity load shedding can go up to four times in one week, each episode lasting for about five hours, and this disrupts the smooth running of daily activities and can also lead to the spoiling of the perishable goods owned by microbusiness owners in the area. To this effect, the respondents in Kamdimi sub-County reported that rooftop solar energy is very reliable and that also does not require regular maintenance in order to promote the smooth running of the micro-businesses and for household use. Related to this statement, one respondent stated:

'Our country (Uganda) is astride the equator and this enables us to receive sunlight energy throughout the year, which we are able to trap using the solar panels to avail us with the needed required energy'

Most of the respondents (94\%) reported that they resorted to using generator that uses petrol and also used hydroelectricity as alternative sources of energy, confirming that rooftop solar energy is reliable to run their microbusinesses and household use in Kamdini sub-County. To affirm the reliability of rooftop solar energy to members of local community in Kamdini subCounty, the study realized that about $80 \%$ of the respondents who have ever used solar energy were still using solar energy at the time of the study, and some respondents $(40 \%)$ who had not been using solar energy reported that they had started using it. This implies that there is not only continued use of solar energy by members of the local community, but new residents are acquiring solar systems and begun using them, signifying a strong reliance on solar for energy needs by microbusinesses and households in Kamdini sub-County. A test of significance was performed using the Pearson correlation test to determine the relationship between previous and current use of solar energy by the respondents. It was revealed that there was a fairly positive relationship $(\mathrm{r}=0.492 ; \mathrm{P}<0.05)$ between previous and present use of solar energy by the respondents (Table 3). This implies that there is continuous use of solar 
energy by members of the local community in Kamdini sub-County probably because of its reliability and can be used for various purposes as shown in Table 2.

Table 3: Relationship between previous and current use of solar energy by the respondents (Source: Researcher's Questionnaire Survey, 2017)

\begin{tabular}{|ll|c|c|}
\hline & & Value & Approx. Sig. \\
\hline Interval by Interval & Pearson's R & .492 & $.000^{\mathrm{c}}$ \\
Ordinal by Ordinal & Spearman Correlation & .429 & $.000^{\mathrm{c}}$ \\
N of Valid Cases & & 126 & \\
\hline
\end{tabular}

\subsection{Cost implications brought about by the use of rooftop solar energy to members of the local community}

Using rooftop solar energy by members of the local community in Kamdini sub-County has been assumed to come with costs and benefits on their daily livelihoods. The benefits to the members of the local community brought about by the use of rooftop solar energy have so far been emulated in sections 4.2 and 4.3 above. However, using rooftop solar energy involves the acquisition of solar panels, inverters, stabilizers and other solar system equipment needed for the proper functioning of the system. In the study area, although members of the local community had to incur some funds for the purchase of the equipment, about $36 \%$ of the respondents reported that using solar energy is affordable while $27 \%$ reported that it is not affordable. The un-affordability of the solar system was supported by the results from the field which showed that about $37 \%$ of the respondents who earned about UGX 100,000 (US \$26) and below per month needed to save for at least ten months to purchase a solar system that cost about UGX 1,000,000 (US \$263), that was deemed to be sufficient for powering their households and running of their microbusinesses. Some other members of the local community (36\%) settled for cheaper solar systems that cost less than UGX 500,000 (US $\$ 132$ ) which they reported as not sufficient enough to run their microbusinesses.

The statistics test for the relationship between the levels of income and purchase of solar panels to sufficiently meet the energy needs of the respondents was significant $(r=0.057$; $\mathrm{P}=0.560$ ) as shown in Table 4. Hence, the level of income of the respondents contributed to the purchasing power of the solar panels in the study area. The high-income earners purchased more solar panels compared to the low-income earners, though majority (95\%) of the respondents had some solar panels of some kind. 


\begin{tabular}{|c|c|c|c|}
\hline & & Value & Approx. Sig. \\
\hline Interval by interval & Pearson's R & .057 & $.560^{\mathrm{c}}$ \\
\hline Ordinal by Ordinal & Spearman Correlation & .019 & $.842^{\mathrm{c}}$ \\
\hline $\mathrm{N}$ of Valid Cases & & 108 & \\
\hline
\end{tabular}

Among the respondents in Kamdini sub-County, $75 \%$ of them reported that the average monthly expense on maintenance of solar systems is about UGX 5,500 (US \$1.5) and it is cheap. This could be the reason why the majority of the population in the study area prefer using rooftop solar energy than other sources like the hydro-electricity, where they are likely to incur higher monthly maintenance costs which are currently at UGX 15,000 (US \$4) in addition to the costs for the power consumption. The respondents reported that the expenses related to the use of rooftop solar power would have been negligible but were brought about by some factors like knowledge and skills of using the rooftop solar system, and also the quality of the solar system purchased.

It can, therefore, be observed that whereas a number of energy sources including rooftop solar energy, hydroelectricity, and biomass are available for use to members of the local community, the majority of them prefer utilizing rooftop solar energy for their household use and running of their microbusinesses. Rooftop solar energy is mainly used for lighting, charging of mobile phones, ironing of clothes among others by members of the local community. Preference for using rooftop solar energy in the study area is because it is more reliable compared to other sources of energy. Once the solar system is installed, it does not attract monthly bills, although sometimes the cost of installing rooftop solar energy may be more than the monthly income for the members of the local community, which may act as a disincentive to use the energy by some members.

\section{Discussion}

Majority of the members of the local community in the study area who operated small microbusinesses utilized rooftop solar energy to meet their energy demands. The reasons for 
its use were mainly because that once installed, rooftop solar energy usage does not accrue huge monthly charges and that its maintenance is cheap compared to other energy supplies like hydroelectricity and others. This is in agreement with some authors [25] who state that people do not use hydroelectricity for example because of many costs that accrue from generating and transporting it to the consumers. Other authors [26,27] intimate that the expenses that are incurred because of the use of some sources of energy like electricity do not favour low-income consumers who lack sufficient and monthly savings to service the energy supply as compared to the use of rooftop solar energy which accrues reduced monthly energy bills to the consumers. Another author [28] states that when rooftop solar energy is used, little or no monthly energy bills are incurred which makes it cost effective to the consumers. Consistent with some other studies elsewhere [4,29] intimate that using some other forms of energy like a generator to meet energy demands is not cost friendly since the generator uses petrol to run and it is more expensive. In addition, using some other forms of energy like kerosene as a source of energy, apart from it being very poisonous to children in cases of incidental ingestion, it is very expensive since it is rated to the cost of petrol (1 litre costs USD 1.1) [30].

More findings revealed that use of rooftop solar energy was more reliable with no power outages as compared to those experienced by members of the local community who used hydroelectricity and generators for example. Hydroelectricity consumers reported that power was switched off at some days of the week which interrupted the smooth running of their business. This was brought about by the low wattage power that could not meet the demands of the consumers in the entire country. These findings are consistent with some studies elsewhere [25,28,31] where it is stated that using rooftop solar energy is more reliable as compared to the use of other energy sources like hydroelectricity which may be unstable for some periods of the week. In addition, they state that more power outages are experienced especially when there are extreme weather events when using electricity as compared to using power stored in batteries. Also, that use of rooftop solar energy is more reliable that because there are no moving parts involved and because that because since energy is not transported, natural impediments are not encountered which may disrupt its supply. Other unreliable sources of energy as reported by some authors [5,32] include wood fuel which has been reported to be scarce as a result of dwindling forested areas in Uganda brought about by its overconsumption, and it is not able to meet household demands [33]. 


\section{Conclusions}

Rooftop solar energy as an alternative source of energy has been utilized by majority of the members of local community in Kamdini sub-County. It is mainly utilized for lighting, charging mobile phones, air conditioning, ironing clothes and cooking of food. Rooftop solar energy has been found to be more reliable towards meeting energy demands to members of Kamdini sub-County as compared to other energy sources like hydroelectricity, use of petrol and biomass among others. Conclusively, once installed on an individual's premise, use of rooftop solar energy has been found to be less expensive compared to other alternative sources of energy. Hence members of the local community are encouraged to install and use rooftop solar energy to meet their energy demands which may contribute to environmental protection.

\section{Acknowledgements}

The study team acknowledges the support and participation of all the respondents who participated in this study.

\section{List of Abbreviations and Acronyms}

$\begin{array}{lll}\text { ETSAP } & - & \text { The Energy Technology Systems Analysis Programme } \\ \text { FAO } & - & \text { The Food and Agriculture Organisation } \\ \text { IEA } & - & \text { International Energy Agency } \\ \text { Kg } & - & \text { Kilogramme } \\ \text { MJ } & - & \text { Mega Joules } \\ \text { MOEMD } & - & \text { Ministry of Energy and Minerals Development } \\ \text { RWEDP } & - & \text { Regional Wood Energy Development Programme } \\ \text { SEFA } & - & \text { Solar Energy for Africa } \\ \text { UBOS } & - & \text { Uganda Bureau of Statistics }\end{array}$




\section{References}

[1] Razykov, T. M., Ferekides, C. S., Morel, D., Stefanakos, E., Ullal, H. S., and Upadhyaya, H. M. 2011. Solar Photovoltaic Electricity: Current status and future prospects. Solar Energy 85, $1580-1608$.

[2] IRENA and IEA-ETSAP. 2013. Solar Photovoltaics. Technology Brief E11.

[3] Muloni, I. N., and Kaliisa, F. A. K. 2013. Energy efficiency in demand for Uganda. World Finance, Kampala, Uganda.

[4] Tushabomwe, K. C. (2006). Causes of Small Business Failure in Uganda. A Case Study from Bushenyi and Mbarara Towns. African Studies Quarterly (8):4

[5] MOEMD. 2012. Uganda National Energy Balance. Ministry of Energy and Mineral Development (MOEMD), Kampala, Uganda

[6] Renewables Portfolio Standard. 2014. Database of State Incentives for Renewables and Efficiency. Retrieved April 19, 2015, from California: Renewables Portfolio Standard.

[7] Sherwood, L. 2014. U.S. Solar Market Trends 2013. Interstate Renewable Energy Council (IREC).

[8] Halper, E. 2014. Rules prevent solar panels in many states with abundant sunlight. Los Angeles Times.

[9] D’Urso, J. 2015. Akon Launches Academy to help provide electricity to 600 million people in Africa. Retrieved May 22, 2015, from huffpost.

[10] FAO. 2002. Assessing Wood Fuel Supply Potentials. GIZ HERA Cooking Energy Compendium. A practical guide book for implementers of cooking energy interventions.

[11] Umar, O. U., Nura, S., Dahiru, M., and Isa, M. A. 2016. Effects of fuel wood exploitation on the environment: A Case Study of Nasarawa Local Government Area, Nasarawa State Nigeria. Dutse Journal of Pure and Applied Sciences. 2(1). Page 195201.

[12] Cerutte, O. P., Sola, P., Cherovoy, A., et al. The Socioeconmic and Environmental Impacts of Wood Energy Value Chains in Sub-Saharan Africa: a systematic map protocol. Environmental Evidence. 4(12).

[13] Mercer, D., and Soussan, J. 1992. Fuel Wood Problems and Solutions. Managing the World's Forests. Geography.

[14] FAO-RWEDP. 1999. Wood Energy and Environment. Regional Wood Energy Development Programme. webmaster@rwedp.org. 
[15] Muteti, F. M. 2005. Wood Fuel Impact on Environment in Kenya. A Case of Dadaab Refuge Camps. A Research Paper Submitted to Economics Department, University of Nairobi in Partial Fulfillment for the Award of Master's Degree in Economics Policy and Management.

[16] Adanu, S. K., Schneider, T., Stimm, B., and Mosandl, R. 2009. Effects of wood fuel production on the environment and people in Adaklu Traditional Area, Ghana. Journal of Food, Agriculture and Environment. Vol.7(1): Page 241-247.

[17] Wood, T. S., and Baldwin, S. 1985. Fuel Wood and Charcoal Use in Developing Countries. Volunteers in Technical Assistance, Arlington, Virginia. Annual Reviews Energy. 10. Page 407-29.

[18] Grainger, A. 1982. Desertification: how people make deserts, how people can stop and why they don't. London International Institute for Environment and Development.

[19] UBOS. (2002). Uganda Population and Housing Census. Uganda Bureau of Statistics, Kampala, Uganda.

[20] Yamane, T. 1967. Statistics. An Introductory Analysis, $2^{\text {nd }}$ Ed. New York. Harper and Row.

[21] Sarantakos, S. 2005. Social Research. Houndmills, Basingstoke, Hampshire RG21 6XS and 175 Fifth Avenue, New York, N.Y.10010 Palgrave MacMillan.

[22] Lindlof, T. R., and Taylor, C. B. 2011. Qualitative Communication Research Methods. $3^{\text {rd }}$ Ed. SAGE Publications, Inc. 2455 Teller Road, Thousand Oaks, California, 91320.

[23] Hoggart, K., Lee, L., and Davies, A. 2002. Researching Human Geography. London, Arnold.

[24] Sarndal, C. 2003. Stratified Sampling. Model Assisted Survey Sampling. New York. Springer. ISBN 0-387-40620-4.

[25] Jurich, L. 2018. Affordable, Clean, Reliable Energy. A better system created by the people, for the people. Sunrun Inc.

[26] Paulos, B., and Paulos, A. 2017. Bringing the Benefits of Solar Energy to Low-Income Consumers. A guide for States and Municipalities. U.S Department of Energy.

[27] UNEP. (2014). Light for Life: Identifying and Reducing the Health and Safety Impacts of Fuel-Based Lighting. United Nations Environment Programme.

[28] SEFA. 2010. Solar Energy for Africa. http://www.solarafrica.org/why-sefa.html.

[29] Mwanje, R. 2003. Power Costs High for Rural Businesses. The Daily Monitor, Kampala, Uganda.

[30] Saundry, P. 2013. Energy Profile for Uganda. The Encyclopedia of Earth. 
[31] Pickrell, K., DeBenedicts, A., Mahone, A., and Price. S. 2013. Cost-Effectiveness of Rooftop Photovoltaic Systems for Consideration in California's Building Energy Efficiency Standards. Energy and Environmental Economics Inc. 101 Montegomery, CA 94104.

[32] FAO. 2010. Planted Forests Uganda. http//:www.fao.org/forestry/country/18316/en/uga.

[33] Sebbit, A., Bennett, K., and Higenyi, J. 2014. Household Energy Demand Perspectives for Uganda in 2025. Makerere University, Department of Mechanical Engineering, Kampala, Uganda. 